\title{
Entrepreneurial Behaviour of King Chilli Growers in Peren District, Nagaland, India
}

\author{
Tzubentula Jamir* and Kaushal Kumar Jha \\ Department of Agricultural Extension, SASRD Medziphema Campus, \\ Nagaland University, Nagaland, India \\ *Corresponding author
}

A B S T R A C T

Keywords

King chilli, entrepreneurial behaviour, Nagaland

\section{Article Info}

Accepted:

12 February 2020 Available Online: 10 March 2020
This study was carried out to examine the socio-personal, economic, psychological characteristics and entrepreneurial behaviour of king chilli growers in Peren district of Nagaland. Findings revealed that majority $(71.67 \%)$ of the respondent had medium level of entrepreneurial behaviour. Correlation analysis revealed that variables viz., income from king chilli cultivation and attitude of farmers had positive and highly significant association with the entrepreneurial behaviour of the respondents. It was also found that variables viz., family size, size of landholding under agriculture, annual income and adoption had positive and significant association with the entrepreneurial behaviour of the respondents. The variable income from king chilli cultivation and attitude were found important in terms of determining the entrepreneurial behavioural pattern of king chilli farmers.

\section{Introduction}

Chilli (Capsicum spp.) belongs to the family Solanaceae. It is a perennial dicotyledonous plant. The economic part of the crop is the fruit that is pungent and aromatic. The archaeological data proved that the human civilization has been cultivating Capsicum since past 7000 years to be used in food recipes for hotness and colouration (Purkayastha et al., 2012). Globally, chilli cultivation is done in an area of around 20.20 million hectare with production of 37.62 million tonnes. India is the largest producer of chillies in the world with a record annual production of 13.76 million tonnes followed by China with a production of 3.0 million tones. 36.57 per cent of the total global chilli production, is contributed by India followed by China which contributes only 7.97 per cent. India also leads in having the maximum area covered under chilli cultivation (Geetha and Selvarani, 2017).

A wide range of chilli varieties have been evolved with distinct characteristics. There 
are about twenty-two wild and five cultivated species under the genus Capsicum, the cultivated species being $C$. annum, $C$. baccatum, $C$. chinense, $C$. frutescens and $C$. pubescens (Bosland, 1996). Among the cultivated species $C$. annum is most widely spread and have worldwide commercial distribution.

In the Northeastern states of India, one of the most popular spices grown is the king chilli (C. chinense). It is grown in the state of Manipur, Assam and Nagaland. King chilli which contains more capsaicin (3-5\%) as compared to any other Indian chilli is a traditional food item of the people of Nagaland and believed to be the original home (Baruah et al., 2014).

In recent years, king chilli is gaining importance in the scientific community as it was reported as the hottest chilli (measuring 855,000 scoville units) in the world, with entry in the "Guinness book of world records" surpassing the "Mexican red savana habaneros" having 5, 77,000 scoville units (Shetalu, 2010). The State Government of Nagaland also got the patent rights of Naga king chilli and got Geographical Indication (GI) from Government of India under Registration and Protection Act, 1999 (Sharma, 2014). Naga king chilli has very high market demand both in domestic and international market. The State Department of Agriculture has developed marketing linkages with Indian Tobacco Company (ITC), Spices Limited, Spices Board of India and the International Competence Centre for Organic Agriculture (ICCOA) Bangalore for marketing of dried Naga king chilli outside the state (Sharma, 2016).

King chilli has great potential for value addition and its chemical constituents are in use in pharmaceutical and food industry as natural colouring etc. It is use for various medicinal treatments like headache, night blindness, rheumatism, arthritis, gastritis, ankylosing spondylitis, digestive diseases (Sarwa et al., 2012) and to reduce chronic congestion (Bhagowati and Changkija, 2009).

King chilli is grown in almost all the districts of the state Nagaland where, Peren has the highest production followed by Dimapur, Mon, and Kohima district. The area under king chilli cultivation has increased tremendously from 600 ha in 2012-2013 to 1385 ha in 2015-2016 with a total production of $2500 \mathrm{MT}$ and $7739 \mathrm{MT}$ respectively (Statistical Handbook of Nagaland, 2015). Peren district covering a total area of 230 ha under king chilli cultivation and production of 1564 MT (Statistical Handbook of Nagaland, 2017) is one of the major crop which has the potential to venture out economically because of its favorable agro climatic conditions. Sensing the huge potentiality of king chilli production in the state of Nagaland the present study was taken up with objective to examine the socio-economic, personal and psychological characteristics of the king chilli farmers and to analyze the entrepreneurial behaviour of the king chilli farmers and factors affecting it.

\section{Materials and Methods}

The present study was conducted in the state of Nagaland. Peren district leads in production of king chilli, therefore it was selected purposively from among the twelve districts of Nagaland. Further, two Rural Development (RD) blocks viz., Peren and Tening were randomly selected and three villages from each of these selected $\mathrm{RD}$ blocks were included for study based on random sampling. The selected villages included New Puilwa, Mpai and Old Peren under Peren RD block while Old Tesen, Upper Sinjol and Azailong under Tening RD block. A total of 120 king chilli farmers were 
selected based on proportionate random sampling.

Socio-economic, personal and psychological characteristics of the king chilli farmers were studied in terms of the variables age, family size, education, size of total land holding, size of land holding under king chilli, total annual income, total annual income from king chilli, training exposure, experience in king chilli cultivation, information source utilization, market orientation, economic motivation, social participation, adoption of improved king chilli cultivation practices, attitude towards improved king chilli cultivation practices and knowledge level on king chilli cultivation. Entrepreneurial behaviour of the king chilli farmers and factors affecting it were studied in specific areas comprising innovativeness, achievement motivation, risk taking ability, decision making ability, entrepreneurial competencies, entrepreneurial intentions and management orientation.

\section{Results and Discussion}

\section{Socio-economic, personal and psychological characteristics of the king chilli farmers}

It was evident from the Table 1 that majority $(71.67 \%)$ of the respondents had age between 30 to 56 years while, 79.17 per cent of them had medium family size ranging from 4 to 9 members. Almost half $(49.17 \%)$ of the respondents were illiterate and only 5.83 per cent of them had education up to PU level. 61.67 per cent of the king chilli growers had 2.47 acre to 4.94 acre of land under agriculture while all $(100 \%)$ of the respondents had less than 2.47 acre of land under king chilli cultivation. 91.67 per cent of the respondents had an annual income ranging .11901 to .245158 while, 82.50 per cent of them had income range of 23844 to .169230 from king chilli cultivation. It was found that 30.00 per cent of the respondents attended training on improved king chilli cultivation during the last five years and 70.00 per cent of them had medium level of experience in traditional method of king chilli cultivation while, 79.17 per cent of them had medium level of utilization of all information sources. Majority (99.17\%) of the respondents had medium level of market orientation with medium level $(90.83 \%)$ of economic motivation. Most (98\%) of the respondents had medium level of social participation with favourable level $(61.67 \%)$ of attitude towards king chilli cultivation while, 84.16 per cent and 92.50 per cent of them had medium level of overall knowledge and adoption of the improved cultivation practices of king chilli. These findings are in accordance with the findings of Jha (2012), Boruah et al., (2015), Mohapatra and Sahu(2012) and Singhal and Vatta (2017).

\section{Entrepreneurial behaviour of the king} chilli farmers and factors affecting it

Table 2 revealed that majority $(83.33 \%)$ of the respondents had medium level of innovativeness with medium level $(73.33 \%)$ of achievement motivation. 79.17 per cent of the respondents had medium level of risk taking ability while, 88.33 per cent of the respondents had medium level of decision making ability. Majority (90.84\%) of the respondent had medium level of entrepreneurial competencies with medium level $(96.66 \%)$ of entrepreneurial intentions and medium level (67.50\%) of management orientation. These findings are in line with the findings of Nagesh (2006), Pawar (2016), Wankhade et al., (2013), Jha (2012) and Boruah et al., (2015).

It was evident that out of all the entrepreneurial attributes exhibited by the king chilli growers, management orientation ranked first followed by risk taking ability, 
achievement motivation, entrepreneurial competencies, innovativeness, decision making ability and entrepreneurial intentions.

Table 3 revealed that majority $(71.67 \%)$ of the respondents had medium level of entrepreneurial behaviour with respect to cultivation and management of king chilli. This might be due to the medium level of innovativeness, achievement motivation, risk taking ability, decision making ability, entrepreneurial competencies, entrepreneurial intentions and management orientation. The findings are in line with the findings of Boruah et al., (2015). Yewatkar et al., (2019) in their research findings also reported that $76.70 \%$ of the garlic growers possessed medium overall entrepreneurial behaviour.

Association between independent variables and entrepreneurial behaviour of the respondents

It was evident from Table 4 that independent variables 'income from king chilli cultivation' and 'attitude' had positive and significant association with the entrepreneurial behaviour of the respondents at $1 \%$ level of probability.
This reveals that the respondents having high income and attitude will exhibit higher level of entrepreneurial behaviour. It was also revealed that independent variables viz., family size, size of landholding under agriculture, annual income adoption had positive and significant association with the entrepreneurial behaviour of the respondents at 5\% level of probability. Similar findings were observed by Boruah et al., (2015). This signifies that the respondents having larger family size, size of landholding under agriculture, annual income and adoption exhibited higher level of entrepreneurial behaviour.

It was also found that independent variables viz., age, education, size of land holding under king chilli cultivation, training exposure, experience in king chilli cultivation, information source utilization, marketing orientation, economic motivation, social participation and knowledge had nonsignificant association with the entrepreneurial behaviour of the respondents. These findings are in accordance with the findings of Somvanshi et al., (2016) Jha (2012).

Table.1 Socio-economic, personal and psychological characteristics of the king chilli farmers $\mathrm{N}=120$

\begin{tabular}{|c|c|c|c|c|}
\hline $\begin{array}{l}\text { Sl. } \\
\text { No. }\end{array}$ & Characteristics & Category & Frequency & $\begin{array}{c}\text { Percentage } \\
(\%)\end{array}$ \\
\hline 1 & $\begin{array}{c}\text { Age } \\
\text { Mean }=40.08 \\
\mathrm{SD}=12.88\end{array}$ & $\begin{array}{l}\text { Less than } 30 \text { years } \\
30-56 \text { years } \\
\text { More than } 56 \text { years }\end{array}$ & $\begin{array}{l}15 \\
86 \\
19\end{array}$ & $\begin{array}{l}12.50 \\
\mathbf{7 1 . 6 7} \\
15.83\end{array}$ \\
\hline 2 & $\begin{array}{c}\text { Family size } \\
\text { Mean }=6.66 \\
\mathrm{SD}=2.33\end{array}$ & $\begin{array}{l}\text { Small (Less than 4) } \\
\text { Medium (4-9) } \\
\text { Large (More than 9) }\end{array}$ & $\begin{array}{l}08 \\
95 \\
17\end{array}$ & $\begin{array}{c}6.67 \\
79.17 \\
14.16\end{array}$ \\
\hline 3 & Education & $\begin{array}{c}\text { Illiterate } \\
\text { Primary } \\
\text { Middle School } \\
\text { High School } \\
\text { PU } \\
\text { Graduate }\end{array}$ & $\begin{array}{l}59 \\
23 \\
20 \\
10 \\
07 \\
01\end{array}$ & $\begin{array}{c}49.17 \\
19.17 \\
16.67 \\
8.33 \\
5.83 \\
0.83\end{array}$ \\
\hline 4 & $\begin{array}{l}\text { Total land holding } \\
\text { under agriculture } \\
\text { Mean }=2.82 \text { acre }\end{array}$ & $\begin{array}{c}\text { Marginal }(<2.47 \text { acre }) \\
\text { Small }(2.47 \text { acre }-4.94 \text { acre }) \\
\text { Medium }(4.95 \text { acre }-9.88\end{array}$ & $\begin{array}{l}44 \\
74 \\
02\end{array}$ & $\begin{array}{c}36.67 \\
\mathbf{6 1 . 6 7} \\
1.66\end{array}$ \\
\hline
\end{tabular}




\begin{tabular}{|c|c|c|c|c|}
\hline & & $\begin{array}{c}\text { acre }) \\
\text { Large }(>9.88 \text { acre })\end{array}$ & 00 & 0.00 \\
\hline 5 & $\begin{array}{l}\text { Total land holding } \\
\text { under king chilli } \\
\text { cultivation } \\
\text { Mean }=0.80 \text { acre }\end{array}$ & $\begin{array}{c}\text { Marginal }(<2.47 \text { acre }) \\
\text { Small }(2.47 \text { acre }-4.94 \text { acre }) \\
\text { Medium }(4.95 \text { acre }-9.88 \\
\text { acre }) \\
\text { Large }(>9.88 \text { acre })\end{array}$ & $\begin{array}{c}120 \\
0 \\
0 \\
0\end{array}$ & $\begin{array}{c}\mathbf{1 0 0 . 0 0} \\
0.00 \\
0.00 \\
0.00\end{array}$ \\
\hline 6. & $\begin{array}{l}\text { Annual income } \\
\text { Mean }=.128530 \\
\mathrm{SD}=.116628 .4\end{array}$ & $\begin{array}{l}\text { Less than . } 11901 \\
.11901-.245158 \\
\text { More than } .24515\end{array}$ & $\begin{array}{c}00 \\
110 \\
10\end{array}$ & $\begin{array}{c}00.00 \\
91.67 \\
8.33\end{array}$ \\
\hline 7 & $\begin{array}{c}\text { Annual income from } \\
\text { king chilli } \\
\text { Mean }=.96537 .5 \\
\mathrm{SD}=.72693 .3\end{array}$ & $\begin{array}{l}\text { Less than . } 23844 \\
.23844-.169230 \\
\text { More than } .169230\end{array}$ & $\begin{array}{l}05 \\
99 \\
16\end{array}$ & $\begin{array}{c}4.17 \\
\mathbf{8 2 . 5 0} \\
13.33\end{array}$ \\
\hline 8 & Training exposure & $\begin{array}{l}1 \text { Day only } \\
\text { No training }\end{array}$ & $\begin{array}{l}36 \\
84\end{array}$ & $\begin{array}{l}30.00 \\
\mathbf{7 0 . 0 0}\end{array}$ \\
\hline 9 & $\begin{array}{l}\text { Experience in king } \\
\text { chilli cultivation } \\
\text { Mean=23.17, } \\
\mathrm{SD}=12.74\end{array}$ & $\begin{array}{l}\text { Low(Less than 10years) } \\
\text { Medium (10 - } 36 \text { years) } \\
\text { High ( } 36 \text { years) }\end{array}$ & $\begin{array}{l}17 \\
84 \\
19\end{array}$ & $\begin{array}{l}14.17 \\
70.00 \\
15.83\end{array}$ \\
\hline 10 & $\begin{array}{l}\text { Overall utilization of } \\
\text { information sources } \\
\text { Mean }=9.65 \\
\mathrm{SD}=2.74\end{array}$ & $\begin{array}{l}\text { Low (less than 6.91) } \\
\text { Medium (6.91 - 12.41) } \\
\text { High(More than 12.41) }\end{array}$ & $\begin{array}{l}04 \\
95 \\
21\end{array}$ & $\begin{array}{c}3.33 \\
\mathbf{7 9 . 1 7} \\
17.50\end{array}$ \\
\hline 11 & $\begin{array}{c}\text { Market orientation } \\
\text { Mean }=1.98 \\
\mathrm{SD}=0.18\end{array}$ & $\begin{array}{l}\text { Low (Less than } 1.80) \\
\text { Medium }(1.80-2.16) \\
\text { High (More than } 2.16)\end{array}$ & $\begin{array}{c}01 \\
119 \\
00\end{array}$ & $\begin{array}{c}0.83 \\
\mathbf{9 9 . 1 7} \\
00.00\end{array}$ \\
\hline 12 & $\begin{array}{c}\text { Economic motivation } \\
\text { Mean }=14.28 \\
\mathrm{SD}=0.83\end{array}$ & $\begin{array}{l}\text { Low (Less than 13.45) } \\
\text { Medium }(13.45-15.11) \\
\text { High (More than 15.11) }\end{array}$ & $\begin{array}{c}02 \\
109 \\
09\end{array}$ & $\begin{array}{c}1.67 \\
\mathbf{9 0 . 8 3} \\
7.50\end{array}$ \\
\hline 13 & $\begin{array}{c}\text { Social participation } \\
\text { Mean }=1.65 \\
\text { SD }=0.52\end{array}$ & $\begin{array}{l}\text { Low (Less than 1.12) } \\
\text { Medium }(1.12-2.17) \\
\text { High (More than 2.17) }\end{array}$ & $\begin{array}{c}00 \\
118 \\
02\end{array}$ & $\begin{array}{c}00.00 \\
\mathbf{9 8 . 3 3} \\
1.67\end{array}$ \\
\hline 14 & $\begin{array}{c}\text { Attitude } \\
\text { Mean=37.16 } \\
\mathrm{SD}=2.14\end{array}$ & $\begin{array}{c}\text { Less favourable }(<35.02) \\
\text { Favourable }(35.02-39.30) \\
\text { Highly favourable }(>39.30)\end{array}$ & $\begin{array}{l}22 \\
74 \\
24\end{array}$ & $\begin{array}{l}18.33 \\
\mathbf{6 1 . 6 7} \\
20.00\end{array}$ \\
\hline 15 & $\begin{array}{c}\text { Knowledge level } \\
\text { Mean }=48.44 \\
\text { SD }=4.79\end{array}$ & $\begin{array}{l}\text { Low (Less than 43.65) } \\
\text { Medium (43.65-53.23) } \\
\text { High (More than53.23) }\end{array}$ & $\begin{array}{c}02 \\
101 \\
17\end{array}$ & $\begin{array}{c}1.67 \\
\mathbf{8 4 . 1 6} \\
14.17\end{array}$ \\
\hline 16 & $\begin{array}{l}\text { Adoption level } \\
\text { Mean=34.66 } \\
\text { SD }=2.09\end{array}$ & $\begin{array}{l}\text { Low (Less than 32.57) } \\
\text { Medium (32.57-36.75) } \\
\text { High (More than 36.75) }\end{array}$ & $\begin{array}{c}00 \\
111 \\
09\end{array}$ & $\begin{array}{c}0.00 \\
\mathbf{9 2 . 5 0} \\
7.50\end{array}$ \\
\hline
\end{tabular}


Table.2 Distribution of respondents based on their entrepreneurial attributes $\mathrm{N}=120$

\begin{tabular}{|c|c|c|c|c|c|c|}
\hline $\begin{array}{l}\text { Sl. } \\
\text { No. }\end{array}$ & $\begin{array}{l}\text { Entrepreneurial } \\
\text { attributes }\end{array}$ & Level & Frequency & $\begin{array}{c}\text { Percentage } \\
(\%)\end{array}$ & $\begin{array}{l}\text { Mean } \\
\text { Score }\end{array}$ & Rank \\
\hline \multirow{3}{*}{1.} & \multirow{3}{*}{ Innovativeness } & Low & 12 & 10.00 & \multirow{3}{*}{10.75} & \multirow{3}{*}{ V } \\
\hline & & Medium & 100 & 83.33 & & \\
\hline & & High & 08 & 6.67 & & \\
\hline \multirow{3}{*}{2.} & \multirow{3}{*}{$\begin{array}{l}\text { Achievement } \\
\text { Motivation }\end{array}$} & Low & 23 & 19.17 & \multirow{3}{*}{11.47} & \multirow{3}{*}{ III } \\
\hline & & Medium & 88 & 73.33 & & \\
\hline & & High & 09 & 7.50 & & \\
\hline \multirow[t]{3}{*}{3.} & \multirow{3}{*}{$\begin{array}{l}\text { Risk Taking } \\
\text { Ability }\end{array}$} & Low & 24 & 20.00 & \multirow{3}{*}{15.06} & \multirow{3}{*}{ II } \\
\hline & & Medium & 95 & 79.17 & & \\
\hline & & High & 01 & 0.83 & & \\
\hline \multirow[t]{3}{*}{4.} & \multirow{3}{*}{$\begin{array}{l}\text { Decision Making } \\
\text { Ability }\end{array}$} & Low & 12 & 10.00 & \multirow{3}{*}{10.50} & \multirow{3}{*}{ VI } \\
\hline & & Medium & 106 & 88.30 & & \\
\hline & & High & 02 & 1.67 & & \\
\hline \multirow[t]{3}{*}{5.} & \multirow{3}{*}{$\begin{array}{l}\text { Entrepreneurial } \\
\text { Competencies }\end{array}$} & Low & 10 & 8.33 & \multirow{3}{*}{11.20} & \multirow{3}{*}{ IV } \\
\hline & & Medium & 109 & 90.84 & & \\
\hline & & High & 01 & 0.83 & & \\
\hline \multirow[t]{3}{*}{6.} & \multirow{3}{*}{$\begin{array}{l}\text { Entrepreneurial } \\
\text { Intentions }\end{array}$} & Low & 02 & 1.67 & \multirow{3}{*}{6.90} & \multirow{3}{*}{ VII } \\
\hline & & Medium & 116 & 96.66 & & \\
\hline & & High & 02 & 1.67 & & \\
\hline \multirow[t]{3}{*}{7.} & \multirow{3}{*}{$\begin{array}{l}\text { Management } \\
\text { Orientation }\end{array}$} & Low & 19 & 15.83 & \multirow[t]{3}{*}{18.79} & \multirow{3}{*}{ I } \\
\hline & & Medium & 81 & 67.50 & & \\
\hline & & High & 20 & 16.67 & & \\
\hline
\end{tabular}

Table.3 Distribution of respondents based on their entrepreneurial behavior $\mathrm{N}=120$

\begin{tabular}{|c|c|c|c|c|c|}
\hline Sl. & $\begin{array}{c}\text { Level of } \\
\text { No. }\end{array}$ & Frequency & $\begin{array}{c}\text { Percentage } \\
(\boldsymbol{\%}) \\
\text { behavior }\end{array}$ & Mean & SD \\
\hline $\mathbf{1 .}$ & Low & 26 & 21.67 & & \\
\hline $\mathbf{2 .}$ & Medium & 86 & $\mathbf{7 1 . 6 7}$ & 122.2 & 6.379 \\
\hline $\mathbf{3 .}$ & High & 08 & 6.66 & & \\
\hline & Total & 120 & 100 & \\
\hline
\end{tabular}


Table.4 Association between independent variables and entrepreneurial behaviour of the respondents

\begin{tabular}{|c|c|c|}
\hline $\begin{array}{l}\text { Sl. } \\
\text { No. }\end{array}$ & Independent variables & $\begin{array}{l}\text { Coefficient of } \\
\text { correlation (r) }\end{array}$ \\
\hline $\begin{array}{l}1 . \\
2 . \\
3 . \\
4 . \\
5 . \\
6 . \\
7 . \\
8 . \\
9 . \\
10 . \\
11 . \\
12 . \\
13 . \\
14 . \\
15 . \\
16 .\end{array}$ & $\begin{array}{l}\text { Age } \\
\text { Family size } \\
\text { Education } \\
\text { Size of landholding under agriculture } \\
\text { Size of land holding under king chilli cultivation } \\
\text { Annual income } \\
\text { Income from king chilli cultivation } \\
\text { Training exposure } \\
\text { Experience in king chilli cultivation } \\
\text { Information source utilization } \\
\text { Marketing Orientation } \\
\text { Economic motivation } \\
\text { Social participation } \\
\text { Attitude } \\
\text { Knowledge } \\
\text { Adoption }\end{array}$ & $\begin{array}{l}-0.10218^{\mathrm{NS}} \\
0.22659^{*} \\
0.11002^{\mathrm{NS}} \\
0.19308^{*} \\
0.15604^{\mathrm{NS}} \\
0.20970^{*} \\
0.28259^{* *} \\
0.11135^{\mathrm{NS}} \\
-0.12164^{\mathrm{NS}} \\
0.12787^{\mathrm{NS}} \\
0.00325^{\mathrm{NS}} \\
-0.06753^{\mathrm{NS}} \\
0.09824^{\mathrm{NS}} \\
0.38074^{* *} \\
0.06562^{\mathrm{NS}} \\
0.19283^{*}\end{array}$ \\
\hline
\end{tabular}

It may be concluded from the study that majority of the king chilli growing farmers were middle aged, had medium size of family, with medium level of farming experience, social participation, market orientation, economic motivation, favourable attitude, overall knowledge level, adoption level and medium level of overall utilization of information sources with respect to king chilli cultivation practices.

While majority of the respondent had medium level of entrepreneurial behaviour. The variables income from king chilli cultivation and attitude were found important in terms of determining the entrepreneurial behaviour of king chilli farmers.

\section{Acknowledgement}

The author thank the farmers of all the selected villages under Peren district, Nagaland for their immense cooperation during the research work and expresses heartfelt gratitude to Prof. K.K.Jha Head, Department of Agricultural Extension, NU: SASRD, Medziphema for providing necessary help and meticulous guidance for accomplishing the research work within the stipulated time.

\section{References}

Baruah, S., Zaman, K., Rajbongshi, P. and Das, S. 2014. A review on recent 
researches on bhut jolokia and pharmacological activity of capsaicin. International Journal of Pharmaceutical Sciences Review and Research, 24 (2): 89-94.

Bhagowati, R. R., and Changkija, S. 2009. Genetic variability and traditional practices in naga king chilli landraces of Nagaland. Asian Agri-History, 13 (3) : 171-80.

Boruah, R., Borua, S., Deka, C. R. and Borah, D. 2015. Entrepreneurial behavior of tribal winter vegetable growers in Jorhat district of Assam. Indian Research Journal of Extension Education, 15 (1) : 65-69.

Bosland, P.W. 1996. Capsicums: innovative uses of an ancient crop. In: Janick, J. (Ed.), progress in new crops. ASHS Press, Arlington, Virginia, pp. 479-487.

Geetha, R. and Selvarani, K. 2017. A study of chilli production and export from India. International Journal of Advance Research and Innovative Ideas in Education, 3 (2) : 205-210.

Jamir, T. 2017. Entrepreneurial behavioural pattern of king chilli farmers in Peren district of Nagaland. M.Sc. (Ag) Thesis, Nagaland University, School of Agricultural Sciences and Rural Development, Medziphema campus, India.

Jha, K. K. 2012. Entrepreneurial behaviour of pineapple growers. Indian Research Journal of Extension Education, Spl Issue (1): 142-5.

Mohapatra, A. S. and Sahu, U. N. 2012. A study of socio-economic and entrepreneurial characteristics of tribals of mayurbhanj district in sabai grass enterprise. International Journal of Management, IT and Engineering, 2 (5) : 426-438.

Nagesh, 2006. Study on entrepreneurial behaviour of pomegranate growers in Bagalkot district of Karnataka. M.Sc.
(Ag) Thesis, University of Agricultural Sciences, Dharwad, India.

Pawar, L. D. 2016. Entrepreneurial behaviour of potato growers' in block Chhindwara district Chhindwara (M.P.). M.Sc. (Ag) Thesis, Jawaharlal Nehru Krishi Vishwa Vidyalaya, Jabalpur, India.

Purkayastha, J., Alam, S.I., Gogoi, H.K. and Singh, L. 2012. Capsicum assamicum sp. nov. (Solanaceae), from Assam, Northeastern India. Ozean Journal of Applied Sciences, 5 : 55-66.

Sarwa, K. K., Kira, J., Sahu, J., Rudrapal, M. and Debnath, M. 2012. A short review on capsicum chinense. Journal of Herbal Medicine and Toxicology, 6 (2) : 7-10.

Sharma, A. 2014. Sustainable economic analysis and extent of satisfaction level of king chilli growers in Nagaland. Agriculture for Sustainable Development, 2 (1) : 71-4.

Sharma, A. 2016. Sustainable economic analysis and constraints faced by the naga king chilli growers in Nagaland. Indian Journal of Agricultural Research, 50 (3) : 220-5.

Shetalu, Vadeo. 2010. Production and marketing of Naga King chilli cultivation in Dimapur district of Nagaland. M.Sc. (Ag) Thesis, Nagaland University, School of Agricultural Sciences and Rural Development, Medziphema campus, India.

Singhal, S. and Vatta, L. 2017. Impact of Krishi Vigyan Kendra on adoption of improved agricultural production practices. International Journal of Science, Environment and Technology, $6(2): 993-1000$.

Somvanshi, R. M., Deshmukh, A. N., Mokhale, S. U. and Godase, S. K. 2016. Entrepreneurial behaviour of vegetable growers. Agriculture Update, 11 (3) : 239-241.

Statistical Handbook of Nagaland. 2015. 
Directorate of Economics and Statistics, Government of Nagaland, Kohima, India.

Statistical Handbook of Nagaland. 2017. Directorate of Economics and Statistics, Government of Nagaland, Kohima, India.

Wankhade, R. P., Sagane, M. A., Mankar, D.
M. 2013. Entrepreneurial behaviour of vegetable growers. Agriculture Science Digest, 33 (2): 85 - 91.

Yewatkar, H., Lahariya, K.T., Raut, A. and Salame, S. 2019. Entrepreneurial behaviour of garlic growers. International Journal of chemical studies, 7(3): 2644-2647.

\section{How to cite this article:}

Tzubentula Jamir and Kaushal Kumar Jha. 2020. Entrepreneurial Behaviour of King Chilli Growers in Peren District, Nagaland, India. Int.J.Curr.Microbiol.App.Sci. 9(03): 1783-1791. doi: https://doi.org/10.20546/ijcmas.2020.903.207 